Research Journal of Applied Sciences 13 (5): 322-327, 2018

ISSN: $1815-932 \mathrm{X}$

(C) Medwell Journals, 2018

\title{
Quantitative Estimation of Factors Influencing the Level of Development of the Competencies of University Graduates
}

\author{
${ }^{1}$ Kelchevskaya Natalya Removna and ${ }^{2}$ Shirinkina Elena Viktorovna \\ ${ }^{1}$ Ural Federal University named after the first President of Russia B.N. Yeltsin, Yekaterinburg, Russia \\ ${ }^{2}$ Surgut State University, Surgat, Russia
}

\begin{abstract}
The relevance of the study is due to the fact that the transition to competency-based approach in teaching is a radical change in education. In this regard, the implementation of competency-based approach in Russian education should form a single educational professional and qualification space. The reserachers note the problems faced by universities as well as the ambiguity of certain categories. Thus, the competency means the purpose of the educational program that focuses on the request of the modern labour market as well as the needs of the individual. In this logic, the qualification resulting from professional training implies that the graduate has certain professional skills. The goal is to investigate the system of indicators affecting the mastering of competencies by graduates of higher educational institutions. The regression-correlation method of analysis makes it possible to form regression models and to assess the statistical significance of these models. The result of the research is the development of a multifactorial model that makes it possible to assess the level of mastering the competencies of university graduates. All this contributes in the mechanism of forming professional competencies of university graduates as carriers of human capital.
\end{abstract}

Key words: Higher education, competencies, regression model, mechanism, carriers, development

\section{INTRODUCTION}

For a long time the system of education was considered to be independent its role was not only to meet the needs of the labor market but also the needs of the individual. A serious problem in the education system is to increase competition on economic and legal structures as well as to find answers to questions about the balance of the labour market (Kelchevskaya and Shirinkina, 2016).

Currently, the Federal Law of 2012 "On education in the Russian Federation" the Federal Act "on education in the Russian Federation" (M.: Publishing House «Omega-1, 2013). Contains many declarative tasks. They are formulated within the context of "how it should be" while the means of getting those tasks done are at the mercy of educational institutions. Each generation of the Federal state educational standards becomes more similar to some framework, a large choice of independence in the formation of the basic postulates of the educational process is also given to educational organizations and at the same time the responsibility for all autonomy is also placed on the educational institution itself.

Requirements to learning outcomes are described in competencies but switching to competency-based model resulted in the fact that the use of competencies existing in the Federal State educational standard of higher education III + was difficult, moreover, they do not take into account the requirements of employers.
The universities mastering the new two-level system of education have been only adapting to the conditions of the competency-based approach of education as they have faced new problems (Kelchevskaya and Shirinkina, 2017) including the task of independant development of professional competencies based on accepted professional standards as well as numerous other problems associated with this transition:

- How it is necessary to strengthen the interrelation of general professional competencies with the areas of professional activity and the labor market?

- There are no professional competencies, the universities should form them independently taking into account accepted professional standards

- Communication of competencies and learning outcomes with potential future professional activities of the graduate is necessary

- "Competency" category was introduced as a result of mastering of basic education program but the Federal Law does not prescribe what the results of the development should be but reflects the requirements for the development of competencies

In this regard, we share the categories of "competencies" and "learning outcomes". Thus, the competency means the purpose of the educational program that focuses on the request of the modern labour market as well as the needs of the

Corresponding Author: Kelchevskaya Natalya Removna, Ural Federal University named after the First President of Russia B.N. Yeltsin, Yekaterinburg, Russia 
individual. Undoubtedly, the goal is something abstract but at the same time, this part of abstraction must be measured and prove that it exists. The results of learning should include an assessment of the achievement of the goal that is the assessment of mastery of these competencies.

The question "Does the study of a discipline form the mastery of competencies?" cannot be answered unambiguously, since, the formulated competencies should be developed in the process of implementing the entire curriculum, rather than one discipline through various means.

In one case, these competencies are formed by methods and technologies of learning, other competencies will be formed outside the curriculum, for example, various extracurricular educational activities, which is also part of the educational program, since, the educational program is not only a curriculum: it includes both the educational process and the activity of the student's society outside the educational process where the formation of competencies also takes place. This raises the question about the center of achievement: "Is it possible to evaluate the achievement of competencies only through final state certification?" as it is stated in the Federal State educational standard. The measurement of competencies should take place using different means and different approaches. Moreover, any development and formation of other competency may often occur only after the formation of one competency or its partial formation. Consequently, the competencies can be developed with the help of such logically verified theoretical model. Therefore, the question of how to measure the level of mastering these competencies by graduates is urgent.

Literature review: Since 2012, the system of Russian education has been in the process of buildup and formation of a competency-based approach. The transition to a competency-based approach in education is a radical change in education which can be partly interpreted as revolutionary. Objectives and contents of education in the organization of educational process are treated as the results of education achieved by the person at a certain educational level completed.

These results mean a certain set of knowledge, abilities and skills that have acquired the form of competencies as a structural component of human capital.

The implementation of a competency-based approach in Russian education should form a single educational, vocational qualification and cultural-value space. Thus, the introduction of a competency-based approach in the education system is aimed at expanding the academic freedom of the university, increased flexibility and adaptability of standards in relation to local, regional, national and international labor markets, strengthening the orientation of the results of education in the face of new demands of all participants of educational services.

In the conditions of modern requirements to graduate existing under the influence of the new situation on the labor market as well as in line with the accelerating pace of information and technology medium development, it was clear that authoritarian-reproductive system of training became obsolete. In these conditions, education focused only on obtaining knowledge, now means a return to the past.

In the context of the topic of this study, it is worth noting the trends of active development of competency-based education approach, which as noted above, refers to the synthesis of general principles such as the meaning of education, the education contents, the organization of the educational process and the assessment of learning.

In scientific discussions, two diametrically opposed points of view on the essence of this concept are singled out. The increasing scrutiny of universities has led to increasing pressure on heads of department to deliver increased performance (Jackson, 1999). One of them, presented in the monograph (Fedorov et al., 2012) is that the notion of competency does not contain any fundamentally new elements that would not be included in the scope of the concept of "skill", all judgments about competence and competency are artificially inflated and designed to hide "the old problems behind the new curtains". The directly opposite point of view is based on a conception that only the position of the competency-based approach could be an adequate reflection of the most profoundly basic aspects of the process of reforming the education system (Shirinkina, 2017).

An analytical review of studies of researchers in the domain of the competency-based approach in education such as Bermus (2005), Kogan (2001) and others, showed that a distinctive characteristic difference between the competent employee and the qualified one is not only their possession of certain knowledge and skills of a competent worker but the ability to implement them in practice. Zvezdova (2015) argue that the new education system is aimed at forming such new qualities of the graduate as a desire for self-education, mastering of new technologies and understanding of their use, teamwork and ability to make independent decisions.

The created system of higher education has developed in the era of modern times and is based on the transfer of knowledge about something. The new European culture impregnating the new education system is sectoral, rational and utilitarian. In this logic, the qualification resulting from professional training implies that the graduate has certain professional skills. Employers do not need a qualification as the 
fragmentation of production functions into activities but competency as a synthesis of skills accumulating the qualification, the teamwork ability, the initiative and the ability to make decisions.

The implementation of a competency-based approach in Russian education should form a single educational, vocational qualification and cultural-value space. Thus, the introduction of a competency-based approach in the education system is aimed at expanding the academic freedom of the university, increased flexibility and adaptability of standards in relation to local, regional, national and international labor markets (Yu et al., 2016) strengthening the orientation of the results of education in the face of new demands of all participants of educational services.

The formation of such a socially and professionally active person as a carrier of human capital requires from the modern higher school the application of completely new methods of work with the goal of forming a competent graduate in all potentially important spheres of life.

Obviously, the model of forming competencies in higher education is quite a complex process and in part is some kind of a closed circle between categories: "competencies", "tasks" and "activities". Obviously, the competency of the educational program should be formed on the basis of disciplines and activities reflected in the curriculum. The methodology of competency formation as a rule is cyclical for the period of mastering the entire training program and the competencies evaluation is carried out at different stages of the curriculum implementation. Activities for the undergraduate may be uniform but the tasks must be different for each direction. Thus, only after the types of activities and tasks have been formulated, it is possible to begin to form the name of competencies, since, the formulation of competencies proceeds from the formulation of tasks. Only in this logical relationship, the effectiveness of the implementation of competencies could be monitored.

At present, the difficulty arises precisely in the formulation of competencies. Some competencies should be formulated through means and technologies, others-within the framework of social activities, i.e., beyond the scope of curriculum and this formation of competency must occur throughout the entire educational program.

Let us turn to the relationship between such federal state educational standards as FSES III and FSES III +. So, FSES prescribes general cultural competencies, general professional and professional and therefore as the necessary learning outcomes in the form of knowledge and skills are projected, a graduate model is formed. The question arises: "How to ensure the acquisition of this knowledge and skills?", i.e., the student must obtain this

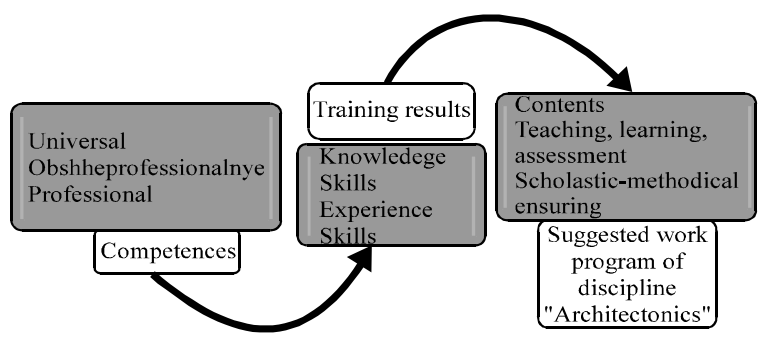

Fig. 1: Model of formation of competencies in the educational process in accordance with the release of FSES VO III + +

knowledge and work skills through the acquisition of competencies, since, it is these components of learning outcomes that are measurable. Therefore, it is these components that must be measured as a result of mastering the disciplines and modules provided for in the curriculum, namely, the funds of evaluation tools reflected in the teaching and methodological support of a discipline or module. Thus, there is an obvious chain that links all parts of the educational process. The model of competencies formation in the educational process is shown in Fig. 1.

It should be noted that with the complexity of the model, the presented chain links the educational process in a complex manner. How should this be implemented? For example, a survey of 100 teachers from the fields "Economics" and "Management" from the same professional group was conducted (Kotlobovsky et al., 2012). Researchers of this study conclude that they got 120 learning outcomes with the same competency, hence, the need to penetrate into the learning outcomes and to identify the factors affecting the level of development of competencies.

\section{MATERIALS AND METHODS}

In this regard, it is advisable to determine the factors that affect the level of mastering of competencies. To collect empirical data, a survey of 107 graduates of 2017 in the areas of the Bachelor's program "Personnel Management", "Economics", "Management" was conducted.

In carrying out econometric analysis of the influence of factors that form the level of mastering competencies by graduates, let us include the following indicators to be investigated:

- $\mathrm{K}_{\mathrm{i}}$ : level of mastery of competency $\mathrm{i}$ by the graduate

- $\mathrm{m}_{\mathrm{n}}$ : motivation of training in this direction

- $\mathrm{c}_{\mathrm{n}}$ : satisfaction with the training in the university

- $\mathrm{I}_{\mathrm{n}}$ : interest in learning in this direction

- $\mathrm{R}_{t \mathrm{t} p}$ : the ratio of theoretical knowledge and practical skills in the training program 
Res. J. Applied Sci., 13 (5): 322-327, 2018

Table 1: Results of regression analysis to determine the factors that affect the development of competencies. Dependent variable-level of mastering the graduate competencies, expressed in points (Model 1)

\begin{tabular}{|c|c|c|c|c|c|c|c|c|}
\hline \multirow[b]{2}{*}{ Model 1} & \multirow{2}{*}{$\begin{array}{c}\text { Non-standardized } \\
\text { coefficients (B) }\end{array}$} & \multirow[b]{2}{*}{$\mathrm{SE}$} & \multirow{2}{*}{$\begin{array}{l}\text { Standardized } \\
\text { coefficients }(\beta)\end{array}$} & \multirow[b]{2}{*}{$\mathrm{t}$-values } & \multirow[b]{2}{*}{ Relevance } & \multicolumn{3}{|l|}{ Of correlation } \\
\hline & & & & & & Of zero order & Partly & Components \\
\hline Constant & 3.371 & 0.274 & & 12.300 & 0.000 & - & - & - \\
\hline $\mathbf{m}_{\mathbf{n}}{ }^{*}$ & -0.131 & 0.047 & -0.199 & -2.802 & 0.006 & -0.077 & -0.283 & -0.123 \\
\hline$c_{n}$ & -0.010 & 0.042 & -0.014 & -0.242 & 0.809 & -0.027 & -0.025 & -0.011 \\
\hline$I_{n}$ & 0.040 & 0.038 & -0.061 & -1.049 & 0.297 & -0.083 & -0.110 & -0.046 \\
\hline $\mathbf{R t}_{\mathrm{p}}{ }^{*}$ & 0.698 & 0.129 & 0.515 & 5.425 & 0.000 & 0.854 & 0.496 & 0.239 \\
\hline$p_{n}{ }^{* *}$ & 0.225 & 0.105 & 0.195 & 2.140 & 0.035 & 0.808 & 0.220 & 0.094 \\
\hline $\mathbf{k}_{\mathbf{t}}^{*}$ & 0.191 & 0.070 & 0.174 & 2.737 & 0.007 & 0.610 & 0.277 & 0.121 \\
\hline $\mathrm{k}_{\mathrm{t}}$ & 0.102 & 0.071 & 0.104 & 1.441 & 0.153 & 0.653 & 0.150 & 0.063 \\
\hline$\alpha_{\mathrm{t}}$ & 0.025 & 0.052 & 0.027 & 0.479 & 0.633 & 0.143 & 0.050 & 0.021 \\
\hline$d_{c}$ & 0.049 & 0.034 & 0.070 & 1.438 & 0.154 & 0.018 & 0.150 & 0.063 \\
\hline$S_{t / w}$ & 0.023 & 0.107 & 0.018 & 0.220 & 0.826 & 0.662 & 0.023 & 0.010 \\
\hline $\mathrm{C}_{t / W}$ & 0.078 & 0.051 & 0.113 & 1.530 & 0.129 & -0.049 & 0.159 & 0.067 \\
\hline $\mathrm{st}_{j w}$ & 0.033 & 0.048 & 0.032 & 0.683 & 0.496 & 0.223 & 0.072 & 0.030 \\
\hline$f_{p}$ & 0.021 & 0.030 & 0.034 & 0.677 & 0.500 & 0.096 & 0.071 & 0.030 \\
\hline $\mathrm{W}_{\mathrm{n}}$ & 0.003 & 0.081 & 0.002 & 0.038 & 0.970 & -0.006 & 0.004 & 0.002 \\
\hline $\mathrm{N}_{\mathrm{n}}$ & 0.012 & 0.024 & 0.024 & 0.514 & 0.608 & 0.044 & 0.054 & 0.023 \\
\hline $\mathrm{Nn}^{2}$ & 0.072 & 0.040 & 0.095 & 1.805 & 0.074 & 0.106 & 0.187 & 0.079 \\
\hline
\end{tabular}

*Significant at the level of $1 \%$ (in bold); **Significant at the level of $5 \%$ (italicized)

- $\mathrm{p}_{\mathrm{n}}$ : the quality of the training and production practices

- $\mathrm{k}_{\mathrm{t}}$ : knowledge and qualifications of scientific and pedagogical staff in this area

- $\mathrm{a}_{\mathrm{t}}$ : objectivity and impartiality of teacher's assessments

- $\mathrm{d}_{\mathrm{c}}$ : the reasons of difficulties in the learning process in the university

- $\mathrm{S}_{\mathrm{t} / \mathrm{w}}$ : the possibility of combining study and work

- $\mathrm{C}_{\mathrm{t} / \mathrm{w}}$ : communication of work in case of overlapping with the received profile

- $s_{t / w}$ : in the case of overlapping was the work an impediment in study

- $\mathrm{f}_{\mathrm{p}}$ : the future scope of the application of labor

- $\mathrm{W}_{\mathrm{n}}$ : possibility of employment

- $\mathrm{N}_{\mathrm{n}}$ : justification of the choice of concentration in the university

- $\mathrm{Nn}^{2}$ : secondary choice of concentration, profile of training in the university

In this connection, we construct regression models where the independent variable is $1 k_{i}$ graduate's familiarization rate of competency (Table 1)

In the resulting regression model 1 which includes the entire scope of the options listed above the results of the econometric analysis have shown that competency development is affected by the following factors at the 0.01 significance level: first place in force of influence takes $\mathrm{R}_{t / \mathrm{p}}$ the Ratio of theoretical knowledge and practical skills in the curriculum, moreover, the higher the prevalence of practical skills above theoretical coefficient, the higher is the development of competencies. This is confirmed by the fact that the question: "If you are not satisfied with some elements of your education in high school, write down what exactly could that be: what knowledge and skills do you lack?" the alumni respond it was practice or practical skills. The second place in significance at level 0.01 with $\mathrm{p}=0.006$ takes mn-motivation of learning, where as part of the main motive is the understanding that this profession is demand in the labour market. The third factor in significance with $\mathrm{p}=0.007$ is $\mathrm{k}_{\mathrm{t}}$ knowledge and qualification of scientific and pedagogical staff in this area. As it was noted above, $75 \%$ of graduates reflect good and excellent knowledge, skills and teaching quality of teachers and $73 \%$ of them note good and great objectivity and impartiality of evaluations.

Such a factor as the $r_{n}$ the quality of educational and industrial practices being held-turned out to be significant at level 0.05 , since as noted above, $48 \%$ of graduates are unhappy with educational and industrial practices being held considering them unnecessary and uninteresting work. The very organization of the practice is held nominally, both by the employer and by the universities. Often the employers themselves see an additional burden in the management of trainees which leads to their removal from necessary and urgent cases, sending them often to unnecessary and uninteresting work. This confirms the idea that a special approach to the formation of competencies is necessary in the qualitative organization of practices from all sides of the participants in the educational process with the aim of increasing the level of mastering competencies.

\section{RESULTS AND DISCUSSION}

To assess the statistical significance of the obtained regression models reflecting the level of mastering of competencies we excluded in turn indicators that do not have a close correlation with the resultant indicator, 
Res. J. Applied Sci., 13 (5): 322-327, 2018

Table 2: Results of regression analysis to determine the factors that affect the development of competencies (Model 2)

\begin{tabular}{|c|c|c|c|c|c|c|c|c|}
\hline \multirow[b]{2}{*}{ Model 2} & \multirow{2}{*}{$\begin{array}{c}\text { Non-standardized } \\
\text { coefficients (B) }\end{array}$} & \multirow[b]{2}{*}{ SE } & \multirow{2}{*}{$\begin{array}{l}\text { Standardized } \\
\text { coefficients }(\beta)\end{array}$} & \multirow[b]{2}{*}{$t$-values } & \multirow[b]{2}{*}{ Significancy } & \multicolumn{3}{|l|}{ Of correlation } \\
\hline & & & & & & Of zero order & Partly & Components \\
\hline Constant & 3.428 & 0.235 & - & 14.587 & 0.000 & - & - & - \\
\hline$m_{n}{ }^{* *}$ & -0.077 & 0.031 & -0.116 & -2.487 & 0.015 & -0.077 & -0.247 & -0.109 \\
\hline $\mathrm{C}_{\mathrm{n}}$ & -0.005 & 0.039 & -0.007 & -0.126 & 0.900 & -0.027 & -0.013 & -0.006 \\
\hline$I_{n}$ & -0.049 & 0.037 & -0.075 & -1.314 & 0.192 & -0.083 & -0.134 & -0.057 \\
\hline $\mathbf{R t}_{\mathrm{p}}{ }^{*}$ & 0.729 & 0.110 & 0.538 & 6.613 & 0.000 & 0.854 & 0.561 & 0.289 \\
\hline$p_{n}^{* *}$ & 0.199 & 0.100 & 0.172 & 1.992 & 0.049 & 0.808 & 0.200 & 0.087 \\
\hline $\mathbf{k}_{t}^{*}$ & 0.202 & 0.069 & 0.184 & 2.951 & 0.004 & 0.610 & 0.290 & 0.129 \\
\hline $\mathrm{k}_{\mathrm{t}}$ & 0.108 & 0.068 & 0.110 & 1.589 & 0.115 & 0.653 & 0.161 & 0.069 \\
\hline$\alpha_{t}$ & 0.039 & 0.050 & 0.043 & 0.785 & 0.435 & 0.143 & 0.080 & 0.034 \\
\hline$d_{c}$ & 0.043 & 0.033 & 0.061 & 1.306 & 0.195 & 0.018 & 0.133 & 0.057 \\
\hline$N_{n}$ & 0.019 & 0.023 & 0.037 & 0.814 & 0.418 & 0.044 & 0.083 & 0.036 \\
\hline $\mathrm{Nn}^{2 * *}$ & 0.087 & 0.037 & 0.116 & 2.393 & 0.019 & 0.106 & 0.238 & 0.105 \\
\hline
\end{tabular}

Table 3: Results of regression analysis to determine the factors that affect the development of competencies (Model 3)

\begin{tabular}{|c|c|c|c|c|c|c|c|c|}
\hline \multirow[b]{2}{*}{ Model 3} & \multirow{2}{*}{$\begin{array}{c}\text { Non-standardized } \\
\text { coefficients (B) }\end{array}$} & \multirow[b]{2}{*}{ SE } & \multirow{2}{*}{$\begin{array}{c}\text { Standardized } \\
\text { coefficients }(\beta)\end{array}$} & \multirow[b]{2}{*}{$\mathrm{t}$-values } & \multirow[b]{2}{*}{ Significancy } & \multicolumn{3}{|l|}{ Of correlation } \\
\hline & & & & & & Of zero order & Partly & Components \\
\hline Constant & 3.770 & 0.198 & - & 19.002 & 0.000 & - & - & - \\
\hline$m_{n}{ }^{* *}$ & -0.061 & 0.031 & -0.092 & -1.973 & 0.050 & -0.077 & -0.195 & -0.089 \\
\hline $\mathrm{C}_{\mathrm{n}}$ & 0.024 & 0.039 & 0.033 & 0.620 & 0.537 & -0.027 & 0.063 & 0.028 \\
\hline$I_{n}$ & -0.066 & 0.038 & -0.101 & -1.741 & 0.085 & -0.083 & -0.173 & -0.078 \\
\hline $\mathbf{R t}_{\mathrm{p} p}{ }^{*}$ & 0.746 & 0.113 & 0.550 & 6.630 & 0.000 & 0.854 & 0.555 & 0.297 \\
\hline$p_{n}{ }^{* *}$ & 0.207 & 0.102 & 0.179 & 2.025 & 0.046 & 0.808 & 0.200 & 0.091 \\
\hline $\mathbf{k}_{\mathrm{t}}{ }^{+}$ & 0.217 & 0.070 & 0.198 & 3.108 & 0.002 & 0.610 & 0.299 & 0.140 \\
\hline $\mathrm{k}_{\mathrm{t}}$ & 0.067 & 0.068 & 0.068 & 0.995 & 0.322 & 0.653 & $0.10-0$ & 0.045 \\
\hline$\alpha_{t}$ & 0.048 & 0.048 & 0.052 & 0.989 & 0.325 & 0.143 & 0.099 & 0.044 \\
\hline
\end{tabular}

*Significant at the level of $1 \%$ (in bold); **Significant at the level of $5 \%$ (italicized)

Table 4: Statistical summary of significance indicators for all models

\begin{tabular}{|c|c|c|c|c|c|c|c|c|c|c|c|}
\hline \multirow[b]{2}{*}{ Models } & \multirow[b]{2}{*}{$\mathrm{R}$} & \multirow[b]{2}{*}{$\mathrm{R}^{2}$} & \multirow[b]{2}{*}{$\begin{array}{l}\text { Corrected } \\
\mathrm{R}^{2}\end{array}$} & \multirow[b]{2}{*}{$\begin{array}{c}\text { Standard } \\
\text { estimation } \\
\text { error }\end{array}$} & \multicolumn{5}{|c|}{ Change history } & \multirow{2}{*}{\multicolumn{2}{|c|}{$\begin{array}{c}\text { No. of } \\
\text { observations }\end{array}$}} \\
\hline & & & & & $\begin{array}{c}\text { Change } \\
\mathrm{R}^{2}\end{array}$ & $\begin{array}{c}\text { Change } \\
\text { F }\end{array}$ & ST.SV.1 & ST.SV.2 & $\begin{array}{c}\text { Val } \\
\text { change F }\end{array}$ & & \\
\hline 1 & 0.909 & 0.825 & 0.794 & 0.39807 & 0.825 & 26.606 & 16 & 90 & 0.000 & 1.515 & 107 \\
\hline 2 & 0.905 & 0.818 & 797 & 0.39512 & 0.818 & 38.947 & 11 & 95 & 0.000 & 1.469 & 107 \\
\hline$\underline{3}$ & 0.896 & 0.802 & 0.786 & 0.40638 & 0.802 & 49.602 & 8 & 98 & 0.000 & 1.358 & 107 \\
\hline
\end{tabular}

receiving the following models, presented in Table 2 and 3. The estimation of statistical significance of the obtained models is given in Table 4.

Comparing the three regression models obtained, it is obvious that with each subsequent elimination of independent factors, the force of influence of factors reflected in the composition of significance increases in addition, the significant factors themselves are supplemented. Thus, in the second regression model, a significant factor appears at the level of $0.05 \mathrm{Nn} 2$.

\section{CONCLUSION}

Regression-correlation analysis made it possible to reveal the correlation force which indicates that such a communication force is significant. Thus, the model reflecting the level of mastering competencies by graduates of higher educational institutions has the form:

$$
\mathrm{K}_{\mathrm{i}}=\alpha_{0}+\alpha_{1} \mathrm{R}_{\mathrm{t} / \mathrm{p}}+\alpha_{2} \mathrm{~m}_{\mathrm{n}}+\alpha_{3} \mathrm{k}_{\mathrm{t}}+\alpha_{4} \mathrm{p}_{\mathrm{n}}
$$

Where:

$\mathrm{K}_{\mathrm{i}}=$ The level of mastering of competencies by the graduate

$\mathrm{R}_{\mathrm{t} / \mathrm{p}}=$ The ratio of theoretical knowledge and practical skills in the training program

$\mathrm{m}_{\mathrm{n}}=$ Motivation of training in this direction

$\mathrm{k}_{\mathrm{t}}=$ Knowledge and qualifications of scientific and pedagogical staff in this area

$\mathrm{p}_{\mathrm{n}}=$ The quality of the training and production practices

The received model testifies that the level of development of competencies is influenced by such parameters as the correlation of theoretical knowledge and practical skills in the training program, the motivation of training in this direction, the knowledge and qualifications of the scientific and pedagogical staff of this direction, the quality of the training and production practices that have passed. All this contributes to the mechanism of forming professional competencies of university graduates as carriers of human capital. 


\section{ACKNOWLEDGEMENT}

The study was prepared while performing research work on the topic "Innovative technologies in regional and municipal management".

\section{REFERENCES}

Bermus, A.G., 2005. [Problems and prospects for the implementation of the equipment approach in education (In Russian)]. Internet Mag. Eidos., 10: 10-12.

Fedorov, A.E., A.A. Soloviev and E.V. Shlyakova, 2012. [Competence Approach in the Educational Process]. Keter Publishing House, Jerusalem, Israel, (In Russian).

Jackson, M.P., 1999. The role of the head of department in managing performance in $\mathrm{UK}$ universities. Intl. J. Educ. Manage., 13: 142-155.

Kelchevskaya, N.R. andE.V. Shirinkina, 2016. [Monitoring the compliance of competencies of graduates of higher education with the requirements of employers (In Russian)]. Econ., 6: 121-129.
Kelchevskaya, N.R. and E.V. Shirinkina, 2017. [Problems of higher education institutions within the framework of the transition to the system of professional standards (In Russian)]. Econ. Educ., 2: 39-47.

Kogan, E.Y., 2001. [Competence approach and new quality of education]. Profi Samara, Samara, Russia. (In Russian)

Kotlobovsky, I.B., E.V. Karavaeva and I.G. Teleshova, 2012. [Monitoring the effectiveness of the implementation of the GEF project: Objectives and criteria (In Russian)]. Higher Educ. Russia, 10: 8-9.

Shirinkina, E.V., 2017. [Competence approach in the system of higher education as a means of creating a unified educational and vocational Crufts qualification space (In Russian)]. Contemp. Sci., 3: 180-188.

Yu, A.S., K.E. Ya and N.V. Tyurina, 2016. [Demand for universities: Approaches to measurement (In Russian)]. Educ., 4: 186-205.

Zvezdova, A.B., 2015. Competence approach in higher professional education. Interregional Institute of Economics and Law, Saint Petersburg, Russia. 